\title{
Mięsak jasnokomórkowy tkanek miękkich podudzia
}

\section{Clear cell sarcoma of soft parts of the leg}

\author{
Mateusz Owsiak ${ }^{\bowtie}$, Anna Walecka \\ Pomorski Uniwersytet Medyczny w Szczecinie, Zakład Diagnostyki Obrazowej i Radiologii Interwencyjnej, ul. Unii Lubelskiej 1, 71-252 Szczecin \\ $\triangle$ matowsiak@gmail.com
}

\begin{abstract}
The authors present the case of a 78-year-old patient with clear cell sarcoma of soft parts of the leg imitating chronic haematoma.
\end{abstract}

\section{ABSTRAKT}

Przedstawiono przypadek 78-letniej pacjentki z mięsakiem jasnokomórkowym tkanek miękkich podudzia lewego imitującym przewlekły krwiak. Omówiono tytułową jednostkę chorobową
We describe the pathology and diagnostic process with emphasis on the role of ultrasonographic examination.

Keywords: clear cell sarcoma; melanoma of soft parts; diagnostics.

i proces diagnostyczny ze szczególnym uwzględnieniem roli badania ultrasonograficznego.

Słowa kluczowe: mięsak jasnokomórkowy; czerniak tkanek miękkich; diagnostyka.

\section{WSTEP}

Mięsak jasnokomórkowy tkanek miękkich jest rzadkim nowotworem złośliwym, który wywodzi się najczęściej ze ścięgien, rozcięgien i powięzi kończyn dolnych [1, 2]. Komórki tego nowotworu wykazują ekspresję markerów różnicowania melanocytarnego, takich jak S-100 i HMB-45, a w ok. 65\% przypadków zawierają melaninę. To podobieństwo do komórek czerniaka w 1983 r. zauważyli Chung i Enzinger, którzy zaproponowali zmianę nazwy tej jednostki chorobowej na „czerniaka złośliwego tkanek miękkich". Pomimo pokrewieństwa i obrazu chorobowego zbliżonego do innych mięsaków nowotwór ten stanowi jednak odrębną, obecnie dobrze udokumentowaną jednostkę chorobową [3, 4]. Należy także zwrócić uwagę, iż pomimo jednobrzmiącej nazwy z mięsakiem jasnokomórkowym nerki nowotwory te należą do zupełnie różnych grup.

Autorzy przedstawili przypadek tytułowej patologii w kontekście diagnostyki ultrasonograficznej.

\section{OPIS PRZYPADKU}

Pacjentka w wieku 78 lat z rozpoznanym reumatoidalnym zapaleniem stawów, osteoporozą i nadciśnieniem tętniczym została przyjęta do Kliniki Reumatologii i Chorób Wewnętrznych Samodzielnego Publicznego Szpitala Klinicznego nr 1 (SPSK-1) Pomorskiego Uniwersytetu Medycznego w Szczecinie (PUM) w celu dalszej diagnostyki i ewentualnej modyfikacji leczenia. $\mathrm{W}$ badaniu przedmiotowym stwierdzono zaczerwienienie oraz obrzęk lewej kończyny dolnej, w związku z czym zlecono wykonanie badania ultrasonograficznego kończyn dolnych. Wykluczona została zakrzepica żył głębokich, jednak badanie wykazało obecność litych niejednorodnych zmian w obrębie lewego uda i podudzia. Na podstawie obrazu klinicznego oraz podwyższonego stężenia parametrów stanu zapalnego wysunięto podejrzenie zapalenia tkanki tłuszczowej, włączono antybiotykoterapię oraz glukokortykosteroidy, uzyskując poprawę stanu klinicznego. Pacjentka została wypisana do domu z odpowiednimi zaleceniami, w tym wykonania kontrolnego badania USG kończyny dolnej lewej, ponieważ obraz zmian w wykonanym badaniu był niejednoznaczny.

Około miesiąca później pacjentka została ponownie przyjęta do Kliniki Reumatologii i Chorób Wewnętrznych SPSK-1 PUM celem dalszej diagnostyki utrzymujących się w kolejnych kontrolnych badaniach USG zmian w kończynie dolnej lewej. $\mathrm{Z}$ uwagi na brak regresji podjęto decyzję o wykonaniu biopsji aspiracyjnej cienkoigłowej. Wynik cytologiczny w korelacji z obrazem klinicznym pozwolił na rozpoznanie mięsaka jasnokomórkowego tkanek miękkich.

\section{DYSKUSJA}

Badanie ultrasonograficzne wyczuwalnych palpacyjnie zmian guzkowych tkanek miękkich obecnie jest coraz częściej pierwszym krokiem w procesie diagnostycznym. Niestety, pomimo postępów technologicznych i stosowania głowic o wysokiej częstotliwości większość zmian litych w tkankach miękkich nie ma charakterystycznych cech ultrasonograficznych, które pozwalałyby postawić jednoznaczne rozpoznanie [5, 6, 7]. W prezentowanym przypadku badanie USG wykazało obecność kilku hipoechogenicznych, niejednorodnych zmian litych, 


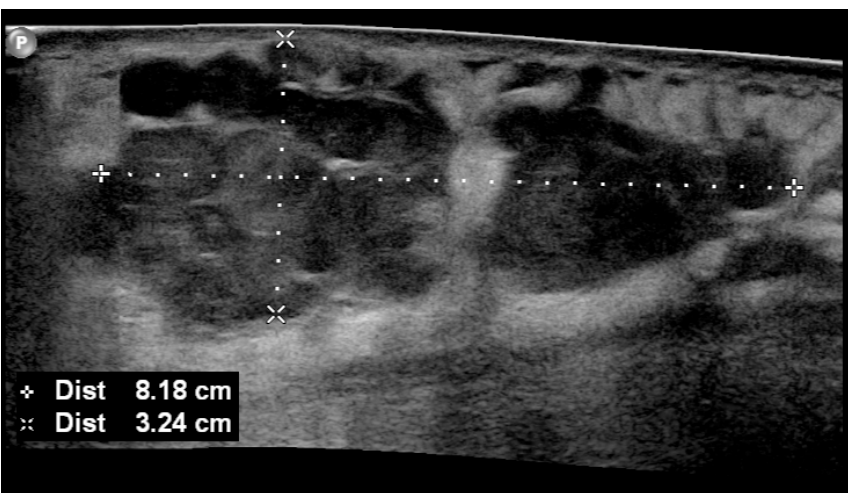

RYCINA 1. Zmiana pierwotna w projekcji podłużnej

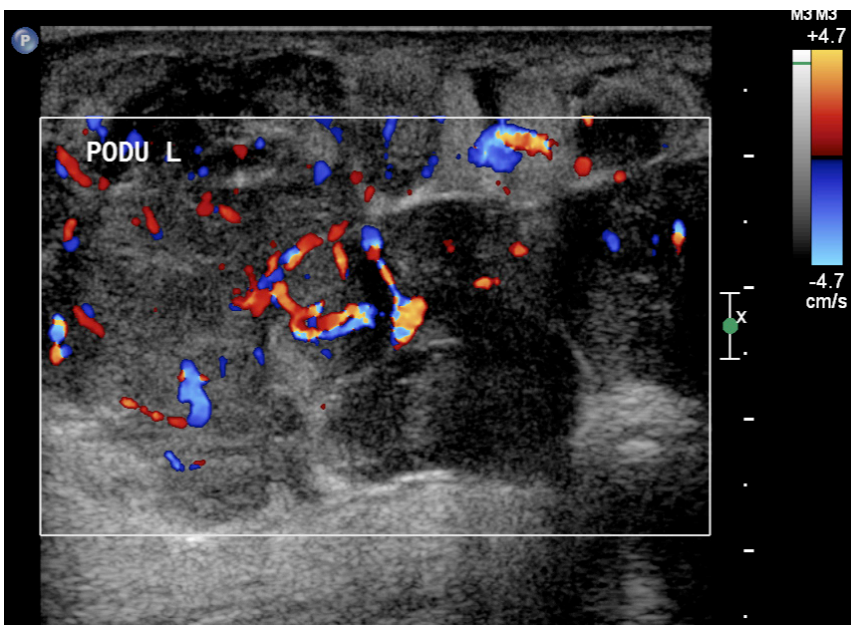

RYCINA 2. Zmiana pierwotna w badaniu dopplerowskim

z różnego stopnia unaczynieniem uchwytnym w badaniu dopplerowskim. Niejasny wywiad nie pozwolił na wykluczenie urazu, a obraz i rozległość samych zmian skłaniały do uwzględnienia w różnicowaniu przewlekłych krwiaków. Pomimo iż zazwyczaj tego typu zmiany nie wykazują wewnętrznego unaczynienia, to ich przewlekła postać z komponentem zapalnym może prezentować różnego stopnia sygnał dopplerowski, co dodatkowo utrudnia proces diagnostyczny [8]. Istotna w tej kwestii jest krótkoterminowa obserwacja. Obraz USG zmian u pacjentki w ciągu kilku nieodległych kontrolnych badań nie wykazywał istotnych zmian, co wzbudziło niepokój onkologiczny, ponieważ krwiak powinien ulegać ewolucji i stopniowej regresji. Wyjątkiem byłby tutaj przewlekle podkrwawiający krwiak, jednak brak zaburzeń z zakresu układu krzepnięcia przemawiał przeciwko temu rozpoznaniu. Biopsja wykonana pod kontrolą USG wykazała złośliwe komórki nowotworowe z ekspresją markerów różnicowania melanocytarnego - cechy mięsaka jasnokomórkowego tkanek miękkich [3, 9]. Za ognisko pierwotne uznano najbardziej zaawansowaną lokalnie zmianę w przyśrodkowej, proksymalnej części podudzia lewego, pozostającą w sąsiedztwie z głową przyśrodkową mięśnia brzuchatego łydki (ryc. 1i 2). Wykryte zmiany na udzie odpowiadają rozsiewowi drogą limfatyczną. Do oceny rozległości procesu wykorzystany został tryb obrazowania panoramicznego, który dodatkowo znacznie ułatwił bezpośrednie

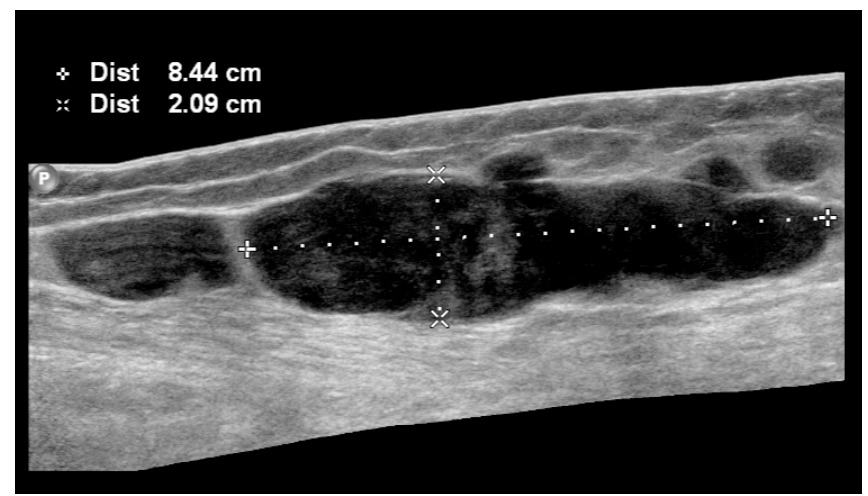

RYCINA 3. Przednia powierzchnia uda lewego. Rozsiew drogą limfatyczną

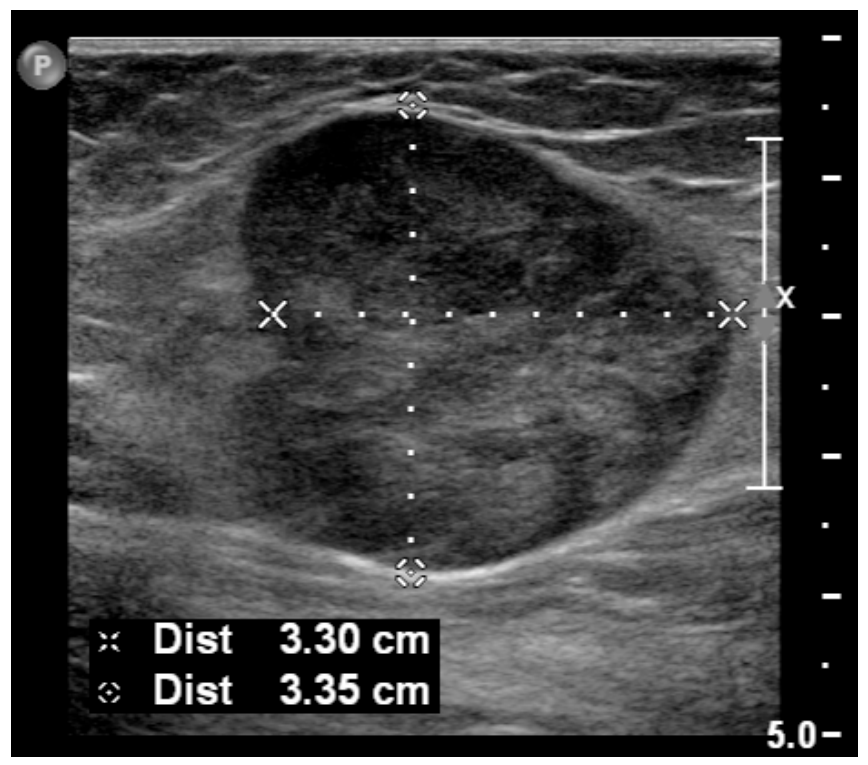

RYCINA 4. Patologiczny węzeł chłonny

porównywanie obrazów pomiędzy kolejnymi kontrolnymi badaniami i pozwolił potwierdzić wzorzec rozsiewu drogą limfatyczną. Wydłużona zmiana na przedniej powierzchni uda (ryc. 3) odpowiada wypełnionemu przez komórki mięsaka kanałowi limfatycznemu pomiędzy kolejnymi węzłami chłonnymi. Najbardziej dystalnie położoną zmianą wtórną był zmieniony węzeł chłonny (ryc. 4) położony w okolicy połączenia żyły odpiszczelowej z żyłą udową. W trakcie hospitalizacji przeprowadzone badania obrazowe nie wykazały zmian wtórnych w obrębie jamy brzusznej i klatki piersiowej. Leczeniem z wyboru mięsaka jasnokomórkowego tkanek miękkich jest resekcja chirurgiczna z ewentualną radioterapią adjuwantową $[10,11]$. Pacjentka została jednak zdyskwalifikowana $\mathrm{z}$ leczenia operacyjnego z uwagi na lokalne zaawansowanie procesu i choroby towarzyszące.

\section{PIŚMIENNICTWO}

1. Chung EB, Enzinger F. Malignant melanoma of soft parts. Am J Surg Pathol 1983;7(5):405-13.

2. Weiss SW, Goldblum JR. Enzinger and Weiss's soft tissue tumors. St Louis: Mosby; 2001. p. 1241-50. 
3. Langezaal SM, Graadt van Roggen JF, Cleton-Jansen AM, Baelde JJ, Hogendoorn PC. Malignant melanoma is genetically distinct from clear cell sarcoma of tendons and aponeurosis (malignant melanoma of soft parts). $\mathrm{Br}$ J Cancer 2001;84(4):535-8. doi: 10.1054/bjoc.2000.1628.

4. Patel RM, Downs-Kelly E, Weiss SW, Folpe AL, Tubbs RR, Tuthill RJ, et al. Dualcolor, break-apart fluo-rescence in situ hybridization for EWS gene rearrangement distinguishes clear cell sarcoma of soft tissue from malignant melanoma. Mod Pathol 2005;18(12):1585-90. doi: 10.1038/modpathol.3800503.

5. Hwang S, Adler RS. Sonographic evaluation of the musculoskeletal soft tissue masses. Ultrasound Q 2005;21(4):259-70.

6. Chiou HJ, Chou YH, Chiu SY, Wang HK, Chen WM, Chen TH, et al. Differentiation of benign and malignant superficial soft-tissue masses using grayscale and color doppler ultrasonography. J Chin Med Assoc 2009;72(6):307-15. doi: 10.1016/S1726-4901(09)70377-6.
7. Beaman FD, Kransdorf MJ, Andrews TR, Murphey MD, Arcara LK, Keeling JH. Superficial soft-tissue masses: analysis, diagnosis, and differential considerations. Radiographics 2007;27(2):509-23. doi: 10.1148/rg. 272065082.

8. Ryu JK, Jin W, Kim GY. Sonographic appearances of small organizing hematomas and thrombi mimicking superficial soft tissue tumors. J Ultrasound Med 2011;30(10):1431-36.

9. Mavrogenis AF, Bianchi G, Stavropoulos NA, Papagelopoulos PJ, Ruggieri P. Clinicopathological features, diagnosis and treatment of clear cell sarcoma/melanoma of soft parts. Hippokratia 2013;17(4):298-302.

10. Deenik W, Mooi WJ, Rutgers EJ, Peterse JL, Hart AA, Kroon BB. Clear cell sarcoma (malignant melanoma) of soft parts: A clinicopathologic study of 30 cases. Cancer 1999;86(6):969-75.

11. Mankin HJ, Hornicek FH. Diagnosis, classification and management of soft tissue sarcomas. Cancer Control 2005;12(2):8-21. 